\title{
Slowing the \\ Wage-Price Spiral: The Macroeconomic View
}

OVER A DECADE has passed since the standard remedy of demand restraint was first urged to combat inflation. By the mid-1960s, many economists, including those at the Council of Economic Advisers, believed war expenditures were pushing the economy into the inflationary, excess-demand zone and recommended tax increases to help restrain aggregate demand. We cannot know how different subsequent economic performance would have been if that advice had been heeded. But it was not. Unemployment continued to decline into 1969 , and the inflation rate in consumer prices rose above 5 percent. Inflation, by then, had become firmly entrenched in economic decisionmaking. When demand finally fell and unemployment rose in the recession of 1970 , the inflation rate scarcely budged. Both average hourly earnings and the private nonfarm price deflator rose faster during 1970-71 than in any year of the 1960s.

Many observers concluded that a recession deeper than that of 1970 would be needed to stop inflation. In summer 1971, the Nixon administration tried a different cure, imposing wage and price controls that lasted in modified form until April 1974. These controls slowed the inflation rate for most wages and prices. But by the time the controls expired, higher prices for food and fuel, which were largely unrelated to the state of demand, and for industrial raw materials, which reflected strong world demand and speculative buying, had created double-digit rates of overall

Note: I am grateful to Jesse M. Abraham for his extensive research assistance. 
Table 1. Wage and Price Inflation in the United States, Selected Periods, 1954-78 Average annual percent change

\begin{tabular}{lcccc}
\hline & \multicolumn{3}{c}{ Private nonfarm economy } & \\
\cline { 2 - 4 } \multicolumn{1}{c}{ Period } & $\begin{array}{c}\text { Hourly } \\
\text { Compensation } \\
\text { per hour }\end{array}$ & $\begin{array}{c}\text { earnings } \\
\text { index }\end{array}$ & $\begin{array}{c}\text { Price } \\
\text { deflator }\end{array}$ & $\begin{array}{c}\text { Consumer } \\
\text { price index }\end{array}$ \\
\hline Post-Korean War (1954-59) & 4.6 & 4.1 & 2.4 & 1.4 \\
Early 1960s (1960-65) & 4.0 & 3.1 & 1.1 & 1.3 \\
Late 1960s (1966-69) & 6.4 & 5.6 & 3.7 & 3.8 \\
Precontrol 1970s (1970-71) & 6.7 & 6.8 & 4.7 & 5.1 \\
Controls (1972-73) & 6.8 & 6.5 & 3.6 & 4.8 \\
Food-fuel explosion (1974-75) & 9.5 & 8.5 & 10.7 & 10.1 \\
1976 & 8.7 & 7.2 & 5.2 & 5.8 \\
1977 & 8.8 & 7.3 & 5.4 & 6.5 \\
1978:1a & $9.1^{\mathrm{b}}$ & $8.0^{\mathrm{b}}$ & 6.3 & 6.6 \\
\hline
\end{tabular}

Source: U.S. Bureau of Labor Statistics.

a. Percent change from the first quarter of 1977 to first quarter of 1978.

b. Without the large increase in the minimum wage in January 1978, the increases would have been an estimated 8.9 percent for compensation and 7.6 percent for hourly earnings.

inflation. Together with a nonaccommodating aggregate-demand policy, this price explosion also started a recession that was double the size of the average previous postwar recession and that lasted until spring 1975.

It is now three years since the trough of this deepest postwar recession. By the end of that recession, inflation had slowed sharply from its 1974 pace, but further improvement was slight once recovery began. From 1975 through 1977, all available measures of tightness in either labor markets or product markets registered ample slack. And no large upward movements have occurred in particular components of the price level since the Organization of Petroleum Exporting Countries increased oil prices in 1974. Yet despite all these disinflationary developments, the rate of inflation, by any broad measure, has continued at a historically high rate and now shows signs of creeping still further upward.

Table 1 summarizes the inflation in the economy since the Korean War as measured by four alternative indexes: compensation per hour, the hourly earnings index, and the price deflator, all of which are averages for the private nonfarm economy; and the consumer price index. Except in 1974 and 1975, when controls ended and oil prices soared, the three measures for the private nonfarm economy have moved closely together, with compensation per hour and the price deflator differing by approximately the trend rate of growth in labor productivity. The consumer price index is more volatile than the deflator. They have differed noticeably 
when the relative prices of food or imports changed a great deal, although the inclusion of these prices is not the only difference between the indexes. By any of these measures, inflation has been noticeably faster in the 1970s than in previous periods. It has been faster since 1975 than in the early 1970s. And it has been faster over the most recent four quarters than in previous years of the present recovery.

Inflation is unpopular. It hampers policymaking and inhibits the pursuit of high employment. This paper provides a basis for evaluating alternative approaches to slowing it.

\section{The Mainline Model}

In this section I briefly outline what I perceive to be the important characteristics of the U.S. economy that have led to the present stubborn inflation. Unlike many journalists describing the stagflation period, I do not conclude that economists fail to understand the economy. And unlike some professional writers of this period, I do not conclude that the Keynesian revolution got everything wrong. However, we have learned during the past ten years that the Keynesian analysis stops short of adequately modeling the inflation process.

Let me begin by describing the essential features of what I call the mainline model of the U.S. macroeconomy. It offers a description of macroeconomic behavior that is compatible with a broad range of more specific models that would have similar policy implications. I later discuss some alternative views of the economy and of the current stagflation that are not consistent with this mainline model and that have policy implications that I believe are basically misleading.

In the mainline model, wage and price behavior are closely linked, and there is at least some mutual causality between them. Because the effect of wages on prices is more predictable and better established, it is useful to begin analyzing the inflation problem by describing the macroeconomics of labor markets.

Wages respond to the tightness of labor markets but not enough to avoid fluctuations in employment brought about by corresponding fluctuations in demand. Thus, something like a Phillips curve exists, at least for periods that are relevant to policymakers and to the conduct of economic affairs, and for the range of unemployment actually experienced. Within this framework, average wages begin to rise at an inflationary rate while unemployment is still well above frictional levels. 
Wages also respond to what has been happening to wages, prices, profit margins, or all three, or to what is expected to happen to them. All these alternatives are accommodated in the mainline model and are discussed further below. What is important is that they all predict considerable inertia in wage inflation. The response of wages to variations in demand is characteristically sluggish.

Some prices are sensitive to demand, particularly prices of industrial raw materials and goods whose costs include a large component of costs for raw materials. Agricultural prices are sensitive to world crop conditions, and prices of tradable goods respond to competition from goods produced abroad. But prices in most of the private sector are closely related to variable costs, the most important of which are labor costs. Given wages, these prices are only slightly affected by demand, and consequently their movement in response to demand variations is also sluggish.

With the possible exception of situations in which unemployment is exceptionally low or industrial operating rates are exceptionally high, variations in aggregate demand lead primarily to variations in output, employment, and unemployment. There can be sustained unemployment arising from inadequate demand. At the aggregate level, the response to variations in demand is similar whether the variation comes from fiscal policy, monetary policy, an unexplained change in velocity, or from some shift in demand from the private sector or from foreign demand for exports.

Within this general description, a number of issues that are important to the design of anti-inflation policy remain open. What is the response of inflation to alternative paths of real activity? Are wages affected by past wages, past living costs, past price margins or profitability, or all three? Is the inertia of inflation essentially backward looking or forward looking; and to the extent that expectations matter, how can they be affected? These are difficult questions that are not easily settled by empirical evidence. But that is a place to begin.

\section{The Empirical Mainline Model}

The empirical counterpart to the model of the inflation process that I have sketched has been presented before with many variations. Although the level of aggregation may differ, the essentials are an equation relating a price deflator for the private sector to wage costs, to materials costs, and 
possibly to some additional effects from demand and the prices of competing imports; and an equation relating wages to the tightness of the labor market and to past or expected future inflation.

I do not present any new results on the price equations. Robert Gordon has recently reviewed the aggregate evidence and reaffirmed that prices change in proportion to wage changes. ${ }^{1}$ Other factors also have an effect, including the costs of raw materials, competing imports, and to a small extent, variations in demand. However, including them in the explanation does not diminish the importance of labor costs.

The principal unsettled issues are concerned with the causes of inertia in wage inflation. I turn first to some disaggregated evidence from the 1960s and 1970s.

\section{DISAGGREGATED WAGE CHANGES}

The first evidence of the stubbornness of inflation came when average wages and prices failed to decelerate much despite rising unemployment after 1969. The behavior of wages in particular sectors is noteworthy during this period. Some wages are set under collective bargaining agreements, frequently with three-year contracts. Many factors can enter into union wage demands in such bargaining situations, including wage levels elsewhere and living costs. There is no well-established model of what unions can successfully bargain for and, especially when contracts are negotiated infrequently and prices and other wages have changed between contracts, new settlements can bear little relation to current unemployment rates. While wages set under collective bargaining may represent an especially obvious departure from short-run market clearing in wage setting, virtually no wages are set in auction markets. Long-term attachments between firms and workers are useful to both sides and characterize a large portion of the job market. In such situations, equity, which may embrace relative wages or inflation, becomes an important consideration in wage setting. Both unionization and long-term attachments characterize some industries more than others. As a consequence, wages in different industries do not move in parallel under changing economic conditions.

High- and Low-Wage Industries. A random sample of 39 industries at the three-digit level of aggregation was divided into groups with high, medium, and low wages according to the average of their hourly earnings

1. Robert J. Gordon, "Can the Inflation of the 1970s be Explained?" BPEA, 1: 1977, pp. 253-77. 
over the 1959-76 period. For each group, the following table shows the average wage increases during the 1960s and 1970s and the difference between the averages for the two periods.

\begin{tabular}{lccc}
\multicolumn{3}{c}{$\begin{array}{c}\text { Average annual percent } \\
\text { Increase in hourly earnings }\end{array}$} \\
\cline { 2 - 3 } $\begin{array}{c}\text { Industry } \\
\text { classification }\end{array}$ & $1959-69$ & $1970-76$ & Acceleration \\
Low wage & 3.8 & 6.5 & 2.8 \\
Medium wage & 3.7 & 6.9 & 3.3 \\
High wage & 3.5 & 7.8 & 4.3
\end{tabular}

After rising slightly more slowly than wages in the low-wage group during the $1960 \mathrm{~s}$, wages in the high-wage group accelerated 4.3 percentage points in the 1970s, compared with an acceleration of 2.8 points for the low-wage group. The consumer price index accelerated by 4.0 points over the same interval. The acceleration of wages in the high-wage industries kept pace over the 1970-76 interval with the acceleration in the consumer price index.

The coefficient of variation of wage levels among the industries sampled declined gradually from 0.20 in 1959 to 0.18 in $1968 . .^{2}$ It then rose gradually to 0.21 in 1974 and then to 0.23 in 1975 and 0.24 in 1976 . Over the period from 1959 to 1976 , an equation of the form developed by Wachter to explain the coefficient of variation $(\mathrm{CV})$ among industry wages produced the following estimates: ${ }^{3}$

$$
\begin{gathered}
C V=0.20-0.10 u^{*-1}+0.26 \Delta \ln C P, \\
(12.0)(-3.2) \quad(2.7) \\
\text { Durbin-Watson }=1.1 ; \text { standard error }=0.11,
\end{gathered}
$$

where $u^{*-1}$ is the inverse of the weighted unemployment rate and $C P$ is the consumer price index. The numbers in parentheses in all equations are t statistics.

Wachter reasoned that wage dispersion was cyclical. He found that the variation was reduced by inflation, which was closely correlated with unemployment in his sample period. Equation 1 supports Wachter's cyclical conclusion that lower unemployment reduces wage dispersion; but it im-

2. Only 38 of the 39 industries were included in the coefficient of variation because wage data for industry 421-3 were available only for 1964-76.

3. Michael L. Wachter, "The Wage Process: An Analysis of the Early 1970s," $B P E A, 2: 1974$, pp. 507-24. 
plies that inflation independently increases it. Stagflation increases it on both counts.

Equations for annual wage increases in individual industries also reveal the relatively stronger effect of inflation and the weaker effect of unemployment in the high-wage industries. Tables $2 \mathrm{a}$ and $2 \mathrm{~b}$ show simple Phillips curves for each of the 26 industries in the low-wage and highwage groups. In each case, the change in hourly earnings adjusted for overtime was regressed on the average increase in the CPI over the two previous years and on the inverse of weighted unemployment. ${ }^{4}$ A dummy variable equal to 1 in 1974 and 1975 was included in each equation to avoid giving undue weight to the observations for those two years. Using annual data, wages in both years were strongly affected by the combination of food and fuel inflation and the end of controls. This situation is examined more carefully below using aggregate wage equations.

Although the individual industry equations are often unsatisfactory, the average coefficient in each group fits the expected pattern. The average coefficient on unemployment is $\mathbf{1 1 . 5}$ for the low-wage industries and 6.8 for the high-wage industries; the average coefficients on the CPI are 0.6 and 0.8 , respectively. Similar results are also obtained when the CPI is replaced by average hourly earnings as the lagged inflation variable. The change in the minimum wage makes no contribution as an additional explanatory variable, even in the low-wage industries. I assume this negative result reflects the poor quality of equations for individual industries. In Gramlich's careful analysis of minimum wages, a 1 percent change in the minimum adds 0.03 percent to average wages. ${ }^{5}$ The impact on wages in low-wage industries should be many times larger than this estimate for the aggregate.

Union Wages. For the past two years, data from the employment cost index have been available for wage and salary increases in occupations both covered and not covered by collective bargaining agreements. Covered wages rose 8.1 and 7.6 percent during 1976 and 1977 , respectively (fourth quarter to fourth quarter). These increases are 1.3 and 1.0 percentage points more than the rise in uncovered wages in the two years.

For years before 1976 , effective union wage changes can be compared

4. The overtime adjustment could not be made for nonmanufacturing industries. Those equations refer to hourly earnings.

5. Edward M. Gramlich, "Impact of Minimum Wages on Other Wages, Employment, and Family Incomes," BPEA, 2:1976, pp. 409-51. 
Table 2a. Disaggregated Wage Change Equations : Low-Wage Industriesa Percent

\begin{tabular}{|c|c|c|c|c|c|}
\hline \multirow{2}{*}{$\begin{array}{l}\text { Standard } \\
\text { industrial } \\
\text { classification } \\
\text { code }\end{array}$} & \multicolumn{3}{|c|}{ Independent variable } & \multirow[b]{2}{*}{$\begin{array}{l}\text { Standard } \\
\text { error }\end{array}$} & \multirow{2}{*}{$\begin{array}{l}\text { Durbin- } \\
\text { Watson } \\
\text { statistic }\end{array}$} \\
\hline & Unemployment & $\begin{array}{c}\text { Lagged } \\
\text { CPI }\end{array}$ & $\begin{array}{c}1974-75 \\
\text { dummy }\end{array}$ & & \\
\hline 23 & $\begin{array}{l}12.60 \\
(2.4)\end{array}$ & $\begin{array}{c}0.46 \\
(2.4)\end{array}$ & $\begin{array}{l}1.79 \\
(1.2)\end{array}$ & 1.74 & 1.7 \\
\hline 22 & $\begin{array}{l}13.40 \\
(3.9)\end{array}$ & $\begin{array}{l}0.54 \\
(4.3)\end{array}$ & $\begin{array}{r}1.87 \\
(2.0)\end{array}$ & 1.13 & 1.6 \\
\hline 203 & $\begin{array}{l}8.90 \\
(2.8)\end{array}$ & $\begin{array}{r}0.73 \\
(6.2)\end{array}$ & $\begin{array}{r}3.51 \\
(4.0)\end{array}$ & 1.05 & 1.4 \\
\hline 25 & $\begin{array}{l}16.02 \\
(7.0)\end{array}$ & $\begin{array}{l}0.53 \\
(6.3)\end{array}$ & $\begin{array}{r}2.39 \\
(3.8)\end{array}$ & 0.76 & 1.8 \\
\hline 39 & $\begin{array}{l}14.31 \\
(6.7)\end{array}$ & $\begin{array}{c}0.53 \\
(6.8)\end{array}$ & $\begin{array}{l}2.51 \\
(4.3)\end{array}$ & 0.70 & 2.4 \\
\hline 367 & $\begin{array}{l}10.18 \\
(2.7)\end{array}$ & $\begin{array}{c}0.41 \\
(3.0)\end{array}$ & $\begin{array}{r}4.67 \\
(4.5)\end{array}$ & 1.25 & 2.4 \\
\hline 365 & $\begin{array}{l}13.12 \\
(2.9)\end{array}$ & $\begin{array}{c}0.64 \\
(3.9)\end{array}$ & $\begin{array}{c}3.86 \\
(3.1)\end{array}$ & 1.47 & 0.9 \\
\hline 209 & $\begin{array}{l}7.00 \\
(2.5)\end{array}$ & $\begin{array}{c}0.67 \\
(6.6)\end{array}$ & $\begin{array}{l}1.21 \\
(1.6)\end{array}$ & 0.92 & 1.3 \\
\hline 243 & $\begin{array}{l}14.35 \\
(6.8)\end{array}$ & $\begin{array}{r}0.88 \\
(11.4)\end{array}$ & $\begin{array}{l}1.85 \\
(3.2)\end{array}$ & 0.70 & 2.7 \\
\hline FIRE $^{\mathbf{b}}$ & $\begin{array}{l}7.82 \\
(3.5)\end{array}$ & $\begin{array}{c}0.38 \\
(4.6)\end{array}$ & $\begin{array}{r}1.81 \\
(2.9)\end{array}$ & 0.75 & 2.2 \\
\hline 364 & $\begin{array}{r}7.77 \\
(2.5)\end{array}$ & $\begin{array}{c}0.61 \\
(5.5)\end{array}$ & $\begin{array}{l}2.58 \\
(3.1)\end{array}$ & 1.01 & 1.4 \\
\hline $52-59$ & $\begin{array}{l}10.77 \\
(5.6)\end{array}$ & $\begin{array}{c}0.39 \\
(5.5)\end{array}$ & $\begin{array}{l}1.87 \\
(3.5)\end{array}$ & 0.63 & 2.6 \\
\hline $375-9$ & $\begin{array}{l}13.83 \\
(2.7)\end{array}$ & $\begin{array}{c}0.54 \\
(2.8)\end{array}$ & $\begin{array}{l}1.48 \\
(1.0)\end{array}$ & 1.72 & 2.5 \\
\hline Mean & 11.5 & 0.56 & 2.4 & $\ldots$ & $\ldots$ \\
\hline
\end{tabular}

See sources and footnotes for table $2 b$.

with changes in the average hourly earnings index, which includes both union and nonunion workers. During most of the 1960s, effective median union wage increases lagged slightly behind the increases in average hourly earnings. Beginning in 1968, data on mean increases are available that show union increases equaling average increases outside the union sector in 1968-69 and then outpacing them in subsequent years.

Table 3 compares the percentage increase in union wages with the increases in the index of average hourly earnings for 1970-77. Union 
Table 2b. Disaggregated Wage Change Equations: High-Wage Industriesa

Percent

\begin{tabular}{|c|c|c|c|c|c|}
\hline \multirow{2}{*}{$\begin{array}{c}\text { Standard } \\
\text { industrial } \\
\text { classification } \\
\text { code }\end{array}$} & \multicolumn{3}{|c|}{ Independent variable } & \multirow[b]{2}{*}{$\begin{array}{c}\text { Standard } \\
\text { error }\end{array}$} & \multirow{2}{*}{$\begin{array}{l}\text { Durbin- } \\
\text { Watson } \\
\text { statistic }\end{array}$} \\
\hline & Unemployment & $\begin{array}{c}\text { Lagged } \\
\text { CPI }\end{array}$ & $\begin{array}{c}1974-75 \\
\text { dummy }\end{array}$ & & \\
\hline 366 & $\begin{array}{c}6.39 \\
(2.1)\end{array}$ & $\begin{array}{c}0.71 \\
(6.3)\end{array}$ & $\begin{array}{c}2.28 \\
(2.7)\end{array}$ & 1.00 & 2.2 \\
\hline 357 & $\begin{array}{r}6.49 \\
(1.8)\end{array}$ & $\begin{array}{r}0.47 \\
(3.5)\end{array}$ & $\begin{array}{r}2.70 \\
(2.7)\end{array}$ & 1.20 & 1.7 \\
\hline 481 & c & $\begin{array}{l}1.18 \\
(4.2)\end{array}$ & $\begin{array}{l}1.25 \\
(0.6)\end{array}$ & 2.58 & 1.7 \\
\hline 356 & $\begin{array}{c}6.96 \\
(3.1)\end{array}$ & $\begin{array}{c}0.68 \\
(8.2)\end{array}$ & $\begin{array}{l}2.45 \\
(3.9)\end{array}$ & 0.75 & 1.6 \\
\hline 335 & $\begin{array}{l}5.41 \\
(1.5)\end{array}$ & $\begin{array}{r}0.81 \\
(6.0)\end{array}$ & $\begin{array}{r}2.34 \\
(2.3)\end{array}$ & 1.23 & 1.2 \\
\hline 352 & $\begin{array}{c}2.79 \\
(0.7)\end{array}$ & $\begin{array}{r}0.57 \\
(4.0)\end{array}$ & $\begin{array}{l}4.80 \\
(4.5)\end{array}$ & 1.27 & 2.3 \\
\hline 353 & $\begin{array}{l}5.76 \\
(2.0)\end{array}$ & $\begin{array}{r}0.77 \\
(7.4)\end{array}$ & $\begin{array}{c}3.41 \\
(4.4)\end{array}$ & 0.93 & 1.2 \\
\hline 354 & $\begin{array}{l}11.94 \\
(6.8)\end{array}$ & $\begin{array}{r}0.66 \\
(10.3)\end{array}$ & $\begin{array}{l}1.88 \\
(3.9)\end{array}$ & 0.58 & 2.0 \\
\hline 331 & $\begin{array}{c}2.72 \\
(0.4)\end{array}$ & $\begin{array}{l}1.01 \\
(4.1)\end{array}$ & $\begin{array}{r}5.31 \\
(2.9)\end{array}$ & 2.21 & 1.7 \\
\hline 12 & $\begin{array}{l}11.54 \\
(1.6)\end{array}$ & $\begin{array}{r}1.17 \\
(4.4)\end{array}$ & $\begin{array}{l}3.16 \\
(1.6)\end{array}$ & 2.36 & 1.8 \\
\hline $421-3$ & c & $\begin{array}{l}0.56 \\
(1.4)\end{array}$ & $\begin{array}{l}-0.86 \\
(-0.3)\end{array}$ & 3.03 & 0.8 \\
\hline 332 & $\begin{array}{l}7.72 \\
(2.5)\end{array}$ & $\begin{array}{l}1.12 \\
(9.7)\end{array}$ & $\begin{array}{l}-0.25 \\
(-0.3)\end{array}$ & 1.04 & 2.5 \\
\hline 371 & $\begin{array}{l}7.31 \\
(1.5)\end{array}$ & $\begin{array}{c}0.64 \\
(3.5)\end{array}$ & $\begin{array}{l}3.37 \\
(2.4)\end{array}$ & 1.65 & 2.2 \\
\hline Mean & 6.8 & 0.80 & 2.5 & $\ldots$ & $\ldots$ \\
\hline
\end{tabular}

Sources: Data from U.S. Bureau of Labor Statistics, with wages in manufacturing industries adjusted for overtime by the author. See text for definitions of the variables.

a. All equations are estimated for the period 1959-76, with a constant term that is not reported. The dependent variable is the percent change in overtime-adjusted hourly earnings. The numbers in parentheses are $t$ statistics. The regression for industry $421-3$ is for the period 1964-76.

b. FIRE is the fire insurance and real estate industries.

c. The unemployment coefficient was negative, so the equation was reestimated without it.

wages rose much faster in 1970 and 1971 when union increases were unaffected by the recession and when unions negotiated to catch up for their small real gains during the late 1960s. During the control years, union wages moved in step with the average. And both accelerated sharply in the two subsequent years of price explosion. For the eight years 
Table 3. Union and Total Private Wage Increases, 1970-77

Percent per year

\begin{tabular}{ccccc}
\hline $\begin{array}{c}\text { Year/ } \\
\text { Period }\end{array}$ & $\begin{array}{c}\text { Effective union } \\
\text { wage-rate } \\
\text { change }^{\mathrm{a}}\end{array}$ & $\begin{array}{c}\text { Increase in index } \\
\text { of average hourly } \\
\text { earnings }\end{array}$ & Difference & $\begin{array}{c}\text { Real union } \\
\text { wage-rate } \\
\text { change }^{\mathrm{b}}\end{array}$ \\
\hline 1970 & 8.8 & 6.6 & 2.2 & 2.9 \\
1971 & 9.2 & 7.0 & 2.2 & 4.9 \\
1972 & 6.6 & 6.6 & 0.0 & 3.3 \\
1973 & 7.0 & 6.4 & 0.6 & 0.8 \\
1974 & 9.4 & 8.2 & 1.2 & -1.6 \\
1975 & 8.7 & 8.8 & -0.1 & -0.4 \\
1976 & 8.1 & 7.2 & 0.9 & 2.3 \\
1977 & 8.0 & 7.3 & 0.7 & 1.5 \\
$1970-77$ & & & & \\
average & 8.2 & 7.3 & 0.9 & 1.7 \\
\hline
\end{tabular}

Source: U.S. Bureau of Labor Statistics.

a. Average effective union wage-rate changes in agreements covering 1,000 or more workers.

b. Effective union wage increases less the increase in the CPI.

as a whole (1970-77), union wages have risen an average of 1 percent a year faster. But while they have outpaced average wages over this period, the 1.7 percent average annual increase in real wages in the union sector during the 1970s just maintained the average rate of real wage increase of the previous decade.

Looking Forward or Backward? The data on union wage increases during the inflationary period of the past decade can help distinguish between forward-looking and backward-looking views of the inflation process. Purely expectational models can have different implications from those that relate current wage and price developments to actual developments of the past. If the inertia in inflation arose from a purely backwardlooking process, current wage setting would be influenced by wage changes that have already occurred elsewhere or by price changes that have occurred since wages currently being set were last changed. The prospect that inflation would accelerate or decelerate in the future would not enter because wage changes would be simply catching up with past events. If the process were purely forward looking, only expectations of future inflation would matter. Bygones are presumably bygones and past changes in wages or prices enter only as people form expectations from them. Unfortunately, analysis with statistical time series is unsuccessful in distinguishing between forward-looking and backward-looking processes when "expectations" are not directly observable and are modeled as 
Table 4. Real and Relative Wage Gains in Major Union Contracts, 1968-75 Percentage points over three years

\begin{tabular}{|c|c|c|c|c|c|}
\hline \multirow[b]{2}{*}{$\begin{array}{c}\text { Contract } \\
\text { year }\end{array}$} & \multirow[b]{2}{*}{$\begin{array}{l}\text { Average } \\
\text { wage gain } \\
\text { (I) }\end{array}$} & \multicolumn{2}{|c|}{ Relative wage gain ${ }^{\mathrm{a}}$} & \multicolumn{2}{|c|}{ Real wage gain ${ }^{\star}$} \\
\hline & & $\begin{array}{l}\text { Forward } \\
\text { looking } \\
\text { (2) }\end{array}$ & $\begin{array}{l}\text { Backward } \\
\text { looking }^{\mathrm{b}} \\
\text { (3) }\end{array}$ & $\begin{array}{c}\text { Forward } \\
\text { looking } \\
\text { (4) }\end{array}$ & $\begin{array}{c}\text { Backward } \\
\text { lookingb } \\
\text { (5) }\end{array}$ \\
\hline 1968 & 19.5 & 0.1 & 3.9 & 4.0 & 9.5 \\
\hline 1969 & 23.4 & 3.2 & 5.7 & 7.8 & 10.9 \\
\hline 1970 & 25.9 & 5.7 & 6.5 & 12.4 & 10.4 \\
\hline 1971 & 26.1 & 6.1 & 5.9 & 12.3 & 10.5 \\
\hline 1972 & 24.9 & 3.7 & 4.7 & 4.4 & 11.4 \\
\hline 1973 & 23.5 & 0.1 & 3.5 & -2.8 & 9.7 \\
\hline 1974 & 25.2 & 1.0 & 4.0 & -0.7 & 4.7 \\
\hline 1975 & 25.7 & 2.4 & 2.3 & 4.3 & -0.6 \\
\hline \multicolumn{2}{|c|}{ Standard deviation } & 2.3 & 1.4 & 5.1 & 4.2 \\
\hline
\end{tabular}

Sources: Union wage changes are calculated as described in notes to this table using data from U.S. Bureau of Labor Statistics on effective wage rate changes. Adjusted average hourly earnings and consumer price indexes are from BLS.

a. Relative wage gain is union wage change (defined in the next note) relative to the change in the average hourly earnings index. Real wage gain is union wage change relative to the change in the consumer price index.

b. The union wage change each year is the increase from current settlements plus average gains in the next two years from prior settlements and escalator provisions. Forward-looking gain is this change less the increase over the same time interval in average hourly earnings or the consumer price index. Backwardlooking gain is this change less the increase in average hourly earnings from three years earlier or the CPI.

lagged values of past inflation. In order to distinguish between the two, it is necessary to turn to other types of evidence.

Various institutional or political arrangements whose purpose is to neutralize, at least partly, the effects of inflation on wages are based on a backward-looking approach. Adjustments in labor contracts to account for increases in the cost of living modify wages according to past changes in the CPI. Such arrangements make it possible to avoid forecasts of future inflation. The minimum wage law has typically been adjusted to take account of past changes in average wages. And the comparability rule for government wages relates them to past changes in wages of workers in the private sector in similar occupations.

Major union wage contracts are the clearest instance of wage commitments made well into the future. If the forward-looking hypothesis works anywhere, it should work in explaining these settlements. Table 4 analyzes wage gains in major union contracts for the period 1968-75. Column 1 shows the estimated average wage gain from settlements over 
the life of the contract, including gains from escalator provisions. ${ }^{6}$ Columns 2 to 5 compare these settlement increases with both past and future changes in the CPI and in adjusted average hourly earnings for the private nonfarm economy. The hypothesis that settlements are forward looking is expressed in columns 2 and 4, where the percentage increases in average earnings throughout the economy and in the CPI over the three-year duration of union settlements are subtracted from the increases under the settlements. Columns 3 and 5 express the hypothesis that settlements are backward looking. There the increase in average earnings for the economy as a whole and in the CPI over the three years ending in the year of the settlement are subtracted from the increases under the settlements. Data are available for these calculations only for the years shown.

Because these major settlements are concentrated in situations that are comparatively insensitive to unemployment rates and presumably sensitive to living costs and relative wages, the hypothesis that yields the less erratic series for wage gains should be preferred. In this case, the backward-looking hypothesis is a more satisfactory one, even though the forward-looking hypothesis is given an advantage in the contest through comparing CPI gains with settlement gains that include escalator adjustments for the same years.

\section{AGGREGATE WAGE EQUATIONS}

I turn now to some aggregate wage equations to observe how well the Phillips curve and alternative specifications of lagged inflation effects predicted wages during the 1970s. Table 5 presents Phillips curve equations for the annual change in adjusted hourly earnings in the private nonfarm sector $(100 \times \Delta \ln E)$, using three alternative lagged inflation variables: the dependent variable, the CPI $(100 \times \Delta \ln C P)$, and the private nonfarm deflator after the effects of the rise in fuel prices in 1974-75 have been removed $(100 \times \Delta \ln D P)$. Two years of lagged inflation are shown in each case, although the second year is frequently insignificant. A thirdyear lag invariably was insignificant and small or wrong-signed. Esti-

6. The average gain from settlements made in year $t$ is estimated by adding the average deferred increases in years $t+1$ and $t+2$ to the average first-year increase in $t$. The deferred increases in each year are averaged over the number of workers who did not receive first-year increases in that year. This procedure is not precise and can only approximate the actual increases that occur over the life of contracts newly negotiated in any given year. 


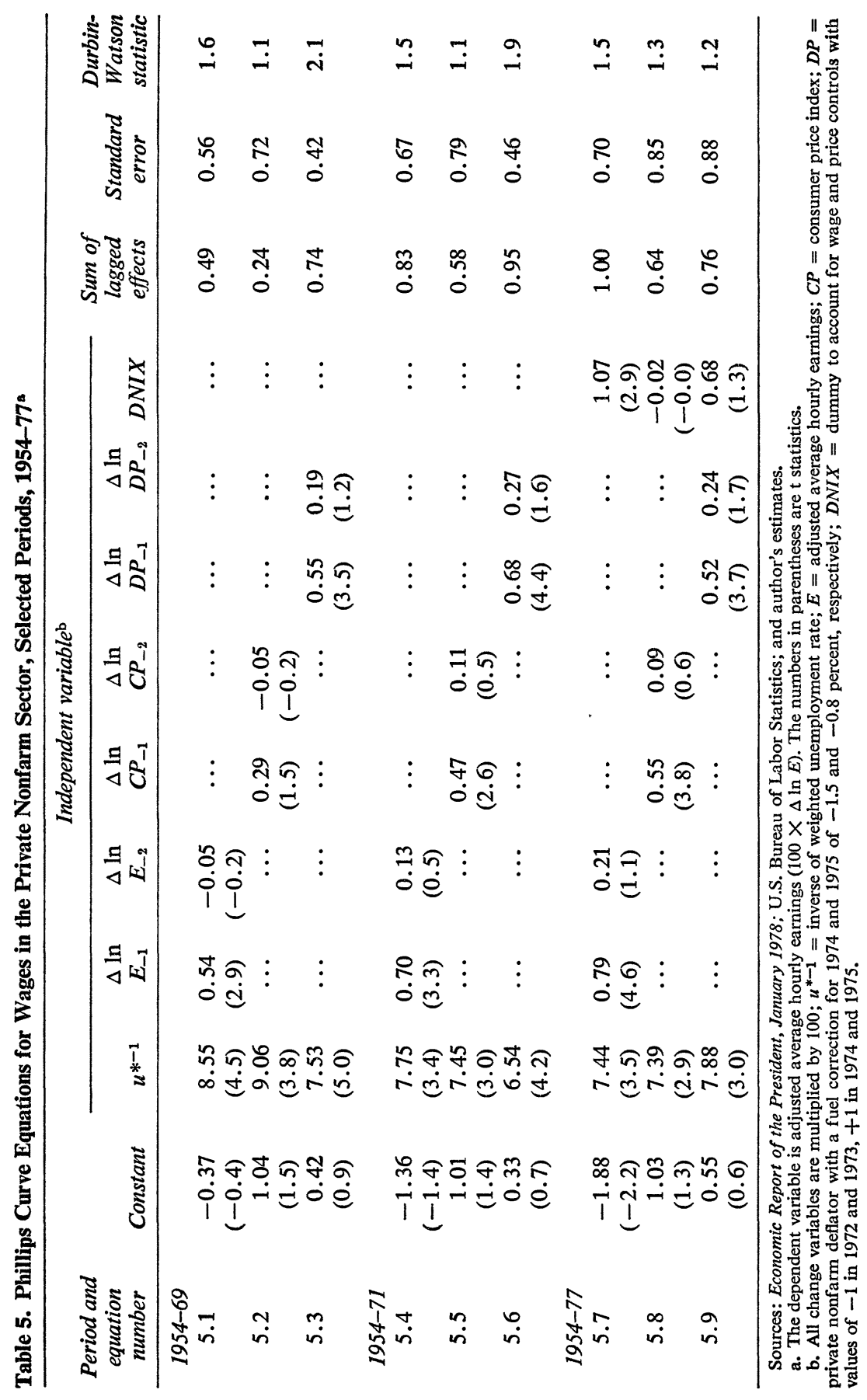


mates are shown for periods beginning in 1954 and ending in 1969, 1971, and 1977.

The quarterly pattern of wage and price changes during 1973-74 clearly points to a discontinuity with the end of controls in the second quarter of 1974. It is difficult to model this situation. Controls were ended when the CPI was already soaring as a consequence of increases in uncontrolled prices of food and fuel and, to a lesser extent, raw materials and imports. Without these price shocks, wages might have behaved differently when controls ended. Nonetheless, in the equation estimated through 1977, I allowed for an amount of wage catch-up in 1974-75 equal to the amount wages were held down in 1972-73 by adding a dummy variable ( $D N I X)$ equal to -1 in 1972 and 1973 and +1 in 1974 and 1975. If one believes that little or no postcontrol "make-up" in wages would have occurred if it had not been for the rapid inflation caused by food and fuel prices, this procedure underestimates the response of wages to that price explosion by attributing a part of actual wage changes in 1974 and 1975 to a reversal of the wage moderation accomplished by controls.

Labor Market Effects. The labor market variable is the weighted unemployment rate, holding constant the 1966 demographic proportions of the labor force. The weighting produces a wage-bill concept of unemployed labor resources; maintaining fixed labor force proportions provides a measure that will not show a change in the tightness of the labor market if the unemployment rate of each group is constant while its relative proportions vary. This measure of weighted unemployment will not capture the possibility that some groups are on flatter or steeper portions of their "own" Phillips curves than other groups. However, it is difficult to model that possibility from available data.

A striking feature of table 5 is that the estimated short-run effect of changing labor market tightness on wages is nearly the same for any of the three periods and for any of the three measures of lagged inflation. They all indicate only a modest first-year effect on inflation from a change in unemployment. For instance, using equation 5.1, an unemployment rate 1 percentage point lower than present levels would add about 0.43 percentage point to the rate of wage inflation, while an increase of 1 percentage point of unemployment would subtract about 0.28 point. Using equation 5.7 , the estimates are 0.37 point and -0.25 point, respectively. The lagged effects would continue to enlarge these impacts, but only 
gradually. In the third year, equation 5.1 predicts that wages would be rising 0.5 percentage point slower if unemployment were sustained at a level 1 point higher, and 0.8 point faster with unemployment sustained 1 point lower. The corresponding third-year estimates from equation 5.7 are 0.7 point slower and 1.0 point faster.

Another way to compare the estimates for different periods is to observe their characterizations of high employment. Equation 5.7, whose lagged wage effects sum to 1.0 , implies that 4.0 percent weighted unemployment-corresponding today to about 5.5 percent conventional unemployment-is consistent with a steady long-run inflation rate. At this weighted unemployment rate, equations 5.1 and 5.4 predict an eventual steady rate of wage increase of 3.5 percent and 3.4 percent. Such wage increases would yield about a 1.5 percent rate of price inflation, which is about as close as the economy ever comes to price stability.

Lagged Effects. Lagged values of the unemployment measure did not enter the wage equation significantly for any period of estimation. Whatever effect there is on average wages from the state of labor markets apparently occurs promptly. However, the influence of lagged inflation is strong and the estimated size of this influence is substantially greater when the 1970s are included in the estimation period.

The straightforward interpretation of this drift in the estimated size of lagged inflation effects is that the significance of ongoing inflation has risen together with the rising rate of inflation. According to this interpretation, so long as rapid inflation was not sustained for an extended period, it was less important in setting wages. Alternatively, it may be that the importance of lagged effects are misestimated in the equations for some periods, and there exists a "true" set of lagged inflation coefficients that is unchanged.

Whether the lagged effects actually sum to 1.0 or to a little less than 1.0 is not important for understanding the current inflation predicament. There will be considerable inertia to inflation with any large value of these lagged effects. When the lagged effects sum to 1.0 , the model has only one unemployment rate at which inflation is predicted to remain unchanged in the long run. For relevant time horizons, the predictions from that model are little different from the predictions of a model that has a longrun trade-off with coefficients on recent inflation summing to 0.8 or so.

The errors for the 1970s from the equations of table 5 are shown in table 6. Even the equations estimated through 1977 show persistent un- 


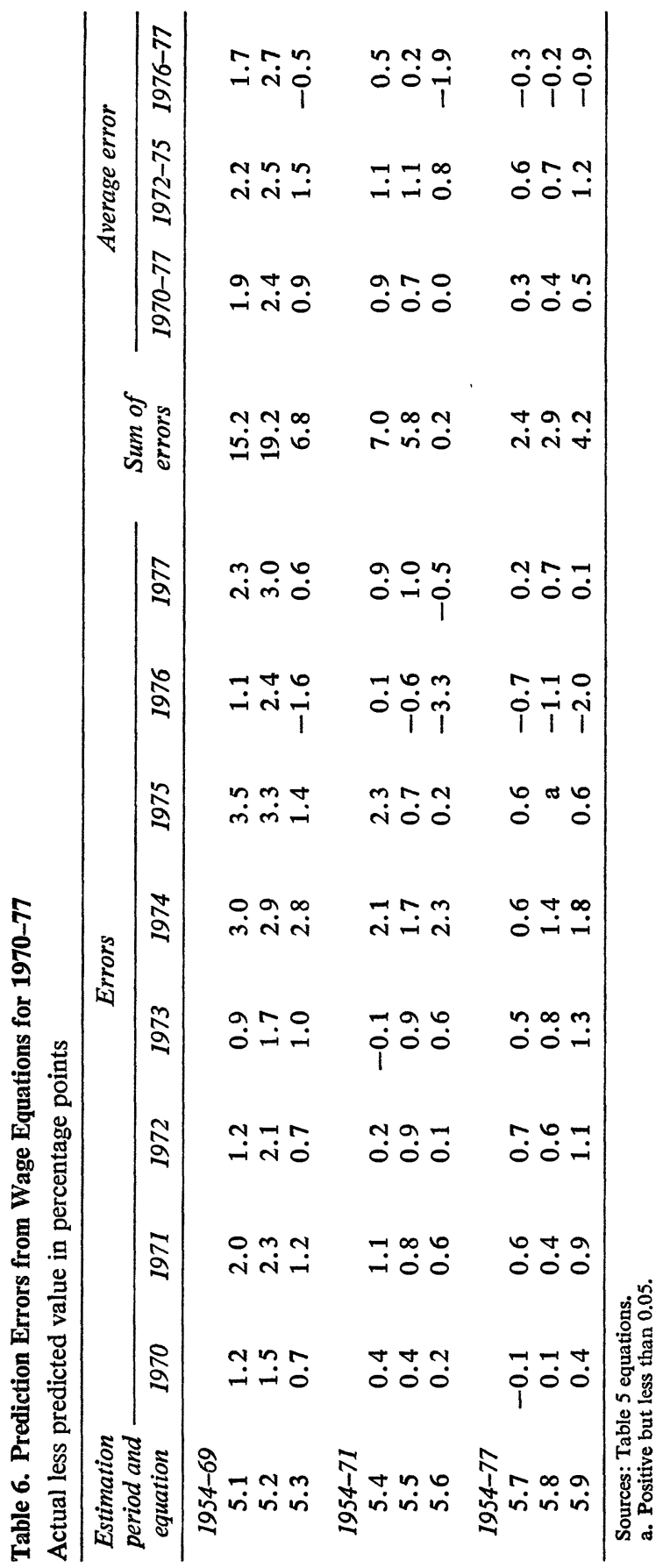


derpredictions through 1975; and in the equations estimated through 1969 , with their smaller lagged effects, the underpredictions are large. The catching up of union wages in 1970-71 and the price explosion of 1974-75 are two events of the period that would not be predictable from aggregate wage equations, and that may help explain the underpredictions of this period.

Lagged CPI. There is no clear preferable alternative among the measures of lagged inflation, although based on the standard errors for all three sample periods, the CPI is unsatisfactory as a single explanatory variable for inertia. The Durbin-Watson statistics for the CPI equations are also consistently low, and when the equations are reestimated with a rho correction, the sum of the lagged CPI coefficients falls to 0.2 in the 1977 regressions. Thus, the estimates give no support to the hypothesis that wages vary in order to attain some real wage level. However, the evidence in favor of some CPI effects on wages is considerably stronger. During the 1976-77 period when inflation slowed substantially, the CPI equations clearly outperformed the equations using the nonfarm deflator. And residuals from any of the equations show that the food-fuel price explosion did affect wage behavior in 1974-75.

Lagged Deflator. The nonfarm deflator provided the best overall fit in the equations estimated through 1969 and 1971, but also provided the worst fit when the sample period was extended to 1977.

The deflator might be expected to work in wage equations for one of two reasons: either because it represents past wage changes that affect current wages, or because changes in the price margins or profitability of firms affect wages. If it is only a proxy for the former effect, then a wage-wage model should be used directly. But occasional observations of rapid wage gains in suddenly prosperous industries-such as coal and oil after 1973 -suggest that profitability may influence wage setting.

Generalized effects of profitability are difficult to find in time-series data. Although early work on Phillips curves found an important role for profits, time-series studies that include the latest decade generally do not. A secular decline in average profitability that coincides with the acceleration of inflation may be masking a causal relation between variations around that secular decline and wage changes. Laurence Seidman, in his paper in this volume, makes such an adjustment and finds that profitability is an important explanatory variable for wages.

Attempts to use both past wages and past deflator prices in the wage 
equation have been unsuccessful. The effect of wage costs on prices makes them highly collinear, and one or the other dominates depending on the sample period. Competition among tradable goods makes the price of imports one source of influence on deflator prices that is independent of wage costs. When the change in the import price of manufactured goods is added to the wage-wage equations of table 5 , that price is significant. However, the equation coefficients are somewhat unstable over the different sample periods. The equations could only be estimated beginning with 1960 because the import price series is not available before 1959 . The equation estimated for $1960-71$, the period before flexible exchange rates, is:

$$
\begin{aligned}
\Delta \ln E=-1.05+7.40 u^{*-1}+ & 0.41 \Delta \ln E_{-1} \\
(-2.4) & (1.8) \\
& +0.42 \Delta \ln E_{-2}+0.11 \Delta \ln M P_{-1} \\
(1.5) & (2.3)
\end{aligned}
$$

Durbin-Watson $=2.6$; standard error $=0.28$.

where all $\Delta \ln$ terms are multiplied by 100 and $M P$ is the price index for finished manufactured imports. For the same equation estimated through 1977 , the sum of the coefficients on the lagged wage term is 0.88 ; and the coefficient on import prices, 0.07 . These equations indicate that beyond the effects of unemployment and a lagged wage elasticity of about 0.85 , a 10 percent change in the price of manufactured import goods alters the price of competing tradable goods by enough to change average wages by about 1 percent. This estimate seems high and should probably not be taken at face value. It does provide some evidence that profit margins have an independent effect on wages, although it is hardly conclusive or successfully quantified.

Lagged Wages. The most robust simple specification of the inertia process seems to be the wage-wage view modeled in equations 5.1, 5.4, and 5.7. Their errors for the two latest years are relatively small, and the two years are tracked rather well without a huge change in the error such as that produced by the deflator equations. The equations fitted through 1969 or 1971, however, greatly underpredict wage changes in subsequent years. The equation estimated through 1977 reduces these overestimates by raising the sum of the lagged wage coefficients to about 1.0.

A close look at the errors in the 1972-75 period shows some direct effect of price inflation on wages. In table 6 the errors from equations 5.1 
or 5.4 declined by about 1 percentage point in 1972-73. This may be interpreted as the direct effect of controls. The errors then jump by over 2 percentage points in 1974-75. There is no wage-wage view of the inflation process that predicts this. The earlier disaggregated results show that the acceleration in 1974-75 was the same in both high-wage and low-wage industries, so the possibility can be ruled out that a distortion of relative wages in the control period led to this acceleration in the average. Even the assumption that controls suppressed a stubborn rate of wage inflation would only account for a return to 1 percent underpredictions. Something between this and no change from the 1972-73 residuals should have been expected if the actual wage experience of 1972-73 affected the wage-wage process and, therefore, wage changes in 1974-75. The actual behavior of wages indicates they responded to the actual behavior of prices.

When the lagged CPI and lagged wages are used together as explanatory variables, the coefficients on unemployment and on wage changes that lag by one year are quite uniform for the three sample periods. The estimated coefficient on the lagged CPI rises from near zero when the equation is estimated through 1969 to about 0.2 in equations estimated through 1971 or 1977 . Wage changes lagged two years only become important when the estimation period is extended to 1977 , raising the sum of all lagged inflation coefficients to 0.93 . The equation fitted to the 1954-71 period (all logs $\times 100$ ) is:

$$
\begin{aligned}
\Delta \ln E=-0.69+7.34 u^{*-1}+ & 0.52 \Delta \ln E_{-1} \\
(-0.7)(3.1) & +0.07 \Delta \ln E_{-2}+0.21 \Delta \ln C P_{-1} \\
& (0.3)
\end{aligned}
$$

Durbin-Watson $=1.8$; standard error $=0.66$.

The prediction errors are:

$\begin{array}{ccccccccc}1970 & 1971 & 1972 & 1973 & 1974 & 1975 & 1976 & 1977 & \text { Sum } \\ 0.2 & 0.8 & 0.3 & 0.2 & 1.7 & 1.3 & -0.4 & 0.9 & 5.0\end{array}$

\section{WAGE BEHAVIOR: CONCLUSIONS}

Once changes in demographics have been allowed for (by measuring tightness in the labor market with the weighted unemployment rate used here), the major change in the inflation-unemployment relation between 
the 1960s and 1970s is associated with the effects of lagged inflation on current wage changes. The existence of large lagged effects created inertia in inflation that transmitted past inflation to current wage changes even when current unemployment rose. In addition, the importance of these lagged effects apparently grew as inflation itself became more entrenched. Today inertia is a more important characteristic of the inflation process than it was in the 1950s and 1960s.

The disappointing experience with inflation during the 1970s can be understood as a consequence of this strong and growing inertia together with some one-time developments that added to inflation during this period. These include, in particular, the catch-up in union wages at the start of the decade and the international explosion of prices for food and fuel before the great recession.

The source of this inertia is not easily identified. Wages in high-wage industries and those set under collective bargaining are relatively insensitive to unemployment and relatively responsive to the ongoing rate of inflation. They may have been particularly important in the failure of average wages to decelerate after 1969. However, for aggregate wages to rise as fast as they have in the 1970s, the ongoing inflation rate must be an important factor in wage determination more generally, possibly as a consequence of patterning other wage changes on those in the high-wage sectors or occupations.

No single explanatory variable adequately describes the effect of past inflation on current wage changes. In general, wages responding to past wages offer a better description of the process than wages responding simply to the CPI. But to explain the developments of the mid-1970s, one needs to believe there was a substantial direct influence of prices on wages as well. This period may have been unusual, but some direct effect of past prices on wages is also estimated in equations such as 3 , which are fitted to long periods that do not include the mid-1970s. In summary, to explain current wage behavior, the importance of ongoing inflation is well established, but the particular importance of ongoing price (as opposed to wage) inflation remains unsettled.

Although it is difficult to disprove the hypothesis that the inertia in aggregate wages represents expected inflation, the estimates favor the more direct hypothesis that inertia is a backward-looking phenomenon. That view is supported directly by the analysis of changes in union wages. In the aggregate equations, it is supported by the fact that inertia appears 
through large coefficients on recent inflation rather than through modest coefficients on inflation rates over a long past period: expectations models generally assert that expectations are adjusted gradually and therefore depend on a long past history of actual inflation. A large coefficient on recent wage changes is most naturally interpreted as a process in which wages are adjusted to keep up continuously with other wages. If these results are taken to mean that expectations are simply formed by the most recent observation of inflation, the expectations hypothesis loses any distinctive significance, for then any change in actual inflation will have a full impact on inflation in the next period, just as the backward-looking hypothesis would predict. Finally, the failure of any lagged values of unemployment to enter the wage equation argues against expected unemployment rates as an important determinant of wage changes.

\section{Alternative Views}

The mainline model that I described at the outset of this paper and the empirical evidence just presented provide a fairly general description of the macroeconomy and the inflation process. Although they leave room for alternative views about the microeconomic underpinnings of inertia and for further research on quantitative questions, they do provide a basis for discussing anti-inflation policies. The blame for inflation or the remedies for it, however, are often argued along lines that are not predicted by the mainline model or from views of the economy that are incompatible with it. Before examining what there is to learn from the mainline model about strategies for slowing inflation, I review some of these dissenting views.

\section{BUDGET DEFICITS}

If a poll were taken to sample opinions on the causes of inflation, most votes would probably go to government deficits. An economist would grant the effects of deficits on aggregate demand and would be hard pressed to find causal links between deficits and inflation over and above their effects on demand. He would also be aware that historically most deficits have come from the operation of automatic stabilizers during periods of underemployment.

Although to my knowledge no serious model predicts that actual 
deficits will explain inflation, equations 4 and 5 were estimated in response to the opinion polls, as follows:

$$
\Delta \ln G P=\frac{-0.0+1.04 L \Delta \ln G P-0.19 L R D G .}{(-0.3)(5.5)}
$$

Period, 1954:1 to 1973:4; Durbin-Watson $=1.7$; standard error $=0.004$.

$$
\Delta \ln G P=0.00+1.11 L \Delta \ln G P+0.00 L R D G+0.003 D N I X .
$$

Period, 1954:1 to 1977:2; Durbin-Watson $=1.8$; standard error $=0.004$.

Four-quarter percentage changes in the GNP deflator $(\triangle \ln G P)$ are explained with Almon lagged values of the deflator itself $(L \Delta \ln G P)$ and of the ratio of the federal deficit to the GNP ( $L R D G$ ). The lags extend 16 quarters. The equations fitted through 1977 include the dummy variable $(D N I X)$ for the control and postcontrol period of the Nixon years that sums to zero. The qualitative results are unaffected by this dummy or by a dummy for the wage-price guideposts of the 1960s. Equation 4, fitted through the end of 1973, reveals the negative effect associated with deficits, which is predicted from the fact that variations in the deficit result primarily from variations in the degree of slack in the economy. When the period is extended to 1977 in equation 5, the coincidence of the price explosion of 1974-75 and the deep recession and consequent large budget deficit raise the coefficient estimated for the deficit to zero.

The actual relationship between budget deficits and economic performance is complicated, and the equations above are not intended to summarize that relationship in any meaningful way. At a minimum, variations in the deficit would have to be decomposed into those that are induced by economic activity and those that represent changes in fiscal policy at a fixed level of utilization. Equations 4 and 5 are intended simply to dispel the view that the present inflation is caused by deficits or that cutting the deficit would help eliminate inflation without causing recession.

The lack of a causal connection between budget deficits and inflation does not deny possibly important linkages between government programs and the current inflation. One important message in Robert Crandall's paper in this volume is that government programs have contributed to inflation by pursuing goals through means that raise the price level rather than through means that show up in the budget deficit. If the costs took the form of federal expenditures or tax credits and thus appeared in the deficit, they would not affect the price level, providing that the level of 
aggregate demand remained the same. Paradoxically, excessive anxiety about deficits can itself be inflationary.

\section{EXCESSIVE GROWTH OF MONEY}

Besides deficits, a close contender in public opinion polls on the causes of inflation would be excessive growth of money. Unlike the deficit explanation, a positive connection between money growth and inflation is acknowledged widely by the professional community. What divides economists is the issue of whether or not a causal role can be assigned to money in addition to its role as a determinant of aggregate demand. The mainline view acknowledges the role of aggregate demand in inflation and the role of money in aggregate demand. It denies any additional, special role of money in causing inflation.

Franco Modigliani and Lucas Papademos have reported on attempts to put money into mainline inflation equations. ${ }^{7}$ Like many other authors, they found a long mean lag for the effect of money on prices when money was used alone in a reduced-form equation. This result is entirely in accord with the view that money affects aggregate demand, thereby promptly influencing real activity and employment, and eventually the inflation rate. But they found that money was insignificant when added to equations that explain prices with the unemployment rate, import prices, and lagged inflation.

Modigliani and Papademos estimated their equations through 1971. By extending the data period, it is possible to modify these results. I explained the annual change in the GNP deflator using the current unemployment rate and three years of lagged values of the change in money and of the dependent variable. When the equation was run from 1954 to 1971, the sum of the coefficients on lagged money was only 0.13 , with successive $\mathrm{t}$ statistics of only $0.6,0.1$, and 0.2 . When the same equation was rerun for the 1954-77 period, the sum of the money coefficients rose to 0.71 with successive $t$ statistics of $1.7,1.2$, and 0.6 . Adding a dummy for the control and postcontrol period raised the sum of coefficients to 0.77. Apparently the recent interest in this type of explanation of inflation arises from the general inability of demand variables to explain the inflation of the mid-1970s and the coincidental acceleration of money growth. All the

7. Franco Modigliani and Lucas Papademos, "Targets for Monetary Policy in the Coming Year," BPEA, 1:1975, pp. 141-63. 
independent explanatory power of money comes from this one episode. To believe that money has this independent role in causing inflation, one has to believe that the relatively rapid money growth of 1972-73 caused the subsequent explosion of prices in 1974-75, creating inflation directly rather than through demand variables for perhaps the first time in history. This interpretation not only strains the imagination, but is inconsistent with the historical evidence of long lags in reduced-form equations explaining prices with money.

\section{SOCIAL WELFARE PROGRAMS}

Government programs of income maintenance would also be high on a list of popular explanations of inflation. Unemployment compensation and the minimum wage are the two programs that are most clearly related to wage behavior. Both have been studied carefully by economists and have at least potentially significant effects on labor markets.

Table 7 shows the percentage of after-tax earnings that was replaced by unemployment benefits and the minimum wage as a percentage of average earnings during recent periods. Both measures rose gradually during the postwar period until the last half of the 1960s. Between 196670 and the present, the net replacement ratio under unemployment compensation increased slightly, while the relative minimum wage declined sharply.

As was noted earlier, Gramlich estimated that average wages rise by about 0.03 percent for each 1 percent change in the minimum. ${ }^{8} \mathrm{~A}$ substantial rise in the minimum, such as the 15 percent increase of January 1978 , will have a noticeable effect on aggregate wages. However, during the period that inflation was worsening, the relative minimum wage was falling. And as the disaggregated results showed, wages in low-wage industries (where increases in the minimum wage have their principal effect) were falling behind other wages. The coverage of the minimum wage was substantially expanded in the mid-1960s, adding to its impact on average wages at that time. But that episode is too remote to have any relevance to the inflation of the 1970s. Finally, by reducing the employment prospects of young workers, the minimum wage may add to their unemployment and thus have a modest effect in shifting the Phillips

8. Gramlich, "Impact of Minimum Wages." 
Table 7. Unemployment Benefits and Minimum Wage Relative to Average Earnings, Selected Periods, 1951-77

Percent

\begin{tabular}{lcccccc}
\hline Description & $1951-55$ & $1956-60$ & $1961-65$ & $1966-70$ & $1971-75$ & $1976-77$ \\
\hline $\begin{array}{l}\text { Unemployment } \\
\text { compensation } \\
\text { replacement } \\
\text { ratio (net)a }\end{array}$ & 39.4 & 42.9 & 44.4 & 46.0 & 47.3 & 47.1 \\
$\begin{array}{l}\text { Relative minimum } \\
\text { wageb }\end{array}$ & 45.4 & 47.6 & 48.3 & 51.1 & 47.2 & 44.3 \\
\hline
\end{tabular}

Sources: Average weekly unemployment compensation benefits, Economic Report of the President, January 1978, table B-33, and updates from U.S. Department of Labor, Employment and Training Administration; spendable earnings (worker with 3 dependents), U.S. Bureau of Economic Analysis, Business Statistics, 1975 (Government Printing Office, 1976) and Survey of Current Business, various issues; straighttime earnings in manufacturing, U.S. Bureau of Labor Statistics, Employment and Earnings, United States, 1909-75, Bulletin 1312-10 (GPO, 1975), and Employment and Earnings, various issues.

a. Unemployment compensation benefits as a percentage of spendable weekly earnings.

b. Minimum wage as a percentage of straight-time hourly earnings in manufacturing.

curve. Any such effect-and I would expect it to be quite small-is captured in using the weighted unemployment rate in the wage equation.

Unemployment compensation has a potential effect on wage inflation by reducing the willingness of recipients to accept available job offers. Together with other programs of income maintenance, it provides a disincentive to work compared with a situation in which no support is provided or one in which support does not depend on unemployment. However, such programs are not new to the recent years of rapid inflation. And as table 7 shows, the benefits have not become much more generous during the period when inflation has worsened.9

In the majority of cases, workers receiving unemployment compensation benefits have been laid off from jobs to which they expect to return. Wages in those jobs are inflexible because of the formal and informal relations binding employers and employees, not because workers who have been laid off are holding back their services waiting for better wages. While unemployment compensation may have some effect on the response of wages to unemployment, it is doubtful that the effect is large.

9. In a series of articles providing many constructive suggestions for reforming the unemployment compensation system, Martin Feldstein has pointed out that replacement ratios for certain workers can rise above the averages shown in table 7. See Martin Feldstein, "Unemployment Compensation: Adverse Incentives and Distributional Anomalies," National Tax Journal, vol. 27 (June 1974), pp. 231-44. However, I doubt that such calculations could alter the verdict that there has been little change in the last decade in the relative benefits of the program. 
The outcome might be different if most of unemployment among those who receive benefits were well described by simple search models and if wage offers were varied by firms in response to short-run variations in labor market tightness. But this is not the case.

MISPERCEPTION, PERFECT MARKETS,

\section{AND RATIONAL EXPECTATIONS}

The most serious conceptual challenge to the mainline model $I$ have outlined comes from a view that attributes all of inflation and unemployment to misperceptions on the part of workers and firms: workers are led into more or less employment than they would normally want by their incorrect reading of wage or price trends. In a related set of models, "rational" expectations and extreme price and wage flexibility are assumed to characterize the macroeconomy. Workers are assumed to make market-clearing wage and price changes continuously, based on the best information available and constrained only by existing contracts. Except for information lags and delays until existing contracts expire, wages and prices are always adjusted to provide equilibrium levels of output and employment. Both these models have an important common feature: in contrast to the mainline model, they have variations in inflation causing variations in unemployment rather than the reverse. Without inflation surprises, unemployment would always be at a "natural rate."

The search models fail to explain the widespread phenomenon of layoffs or the cyclical pattern of quits. To the extent they predict that wages must accelerate if unemployment is to be maintained below its natural rate-their central implication-they predict wages must decelerate if unemployment is to stay above the natural rate for any sustained period. Alternatively, they may assume that misperceptions about available wage offers take a long time to be corrected. On the basis of this argument, the persistence of unemployment and inflation since the mid-1970s is understood as a continued overoptimism about available wage offers. Because most periods of unemployment have a duration measured in days or at most several weeks, it seems unrealistic to assume years of misperception to explain unemployment.

Models that combine wage and price flexibility with assumptions embodied in rational expectations about behavior have similar problems explaining persistence. Any deviation of unemployment from the natural 
rate can persist only until people become aware of the situation or renegotiate existing contracts. Except for three-year wage agreements negotiated with some large unions-agreements that cover only a small fraction of the work force-it is difficult to imagine price or wage arrangements in any important area of the economy that are bound by long-term contracts. Thus, when unemployment has deviated from past levels for any sustained period, the new unemployment level must be interpreted as a new natural rate. By contrast, the mainstream model that I have described recognizes sustained periods of underemployment and leaves open the possibility of changing unemployment through demand management.

\section{Slowing Inflation: Aggregate Demand and Expectations}

The inflation of the 1970s does not change the conclusion that slowing the economy and raising unemployment can slow and eventually eliminate inflation. The evidence is, however, that inflation would slow only gradually in response to holding back aggregate demand, and that the cost in lost employment and output per point of disinflation would be large. The equations of table 5 generally predict inflation will be less than one point slower in the third year of a policy that holds the unemployment rate one point higher. And the additional unemployment implies a loss of $\$ 50$ billion to $\$ 60$ billion a year in output in today's economy.

A different specification might alter the numerical estimates, but it could not reverse the verdict that the anti-inflation gains from restraining aggregate demand are disappointingly small. Arthur Okun recently summarized the estimates from six different econometric models and came to a similarly pessimistic conclusion. ${ }^{10}$ Whatever view is held on the urgency of slowing inflation today, it is unrealistic to believe that the public or its representatives would permit the extended period of high unemployment required to slow inflation in this manner.

Stabilization strategy since 1975 may be interpreted as an attempt to find an output path that would gradually reduce unemployment and at the same time slow inflation. The evidence of the past few years provides little hope for such a possibility. After the hourly earnings index slowed in the early quarters of recovery, it began to accelerate gradually in 1977.

10. Arthur M. Okun, "Efficient Disinflationary Policies," American Economic Review, vol. 68 (May 1978), pp. 348-52. 
Equations based on the level of tightness in the labor market predicted a continuing deceleration given the slack labor markets of 1976-77. But the predicted unwinding of inflation in response to unemployment is so gradual that it is easily offset by other inflationary developments. Food and import prices rose faster in 1977 than in 1976, although the effect on wages of their speedup in 1977 should have been slight. Unemployment declined noticeably during 1977 , and this could help explain the wage speedup if the change in unemployment as well as its level has an effect on wage inflation that is not captured in estimates using annual data. ${ }^{11}$ But whatever the explanation is for recent wage changes, such developments further dramatize the difficulty of slowing the present inflation with demand management alone.

\section{Slowing Inflation: Expectations}

William Fellner has articulated the principal challenge to the pessimistic verdict on using aggregate demand to slow inflation. ${ }^{12} \mathrm{He}$ views the inertia of inflation as a consequence of generalized expectations of inflation. According to Fellner, in recent years contracts governing wages and prices have been formulated with the expectation that inflation will continue into the future..$^{13}$ So long as these expectations are maintained, they become a self-fulfilling prophecy. To stop inflation, policy must change these expectations. In Fellner's view, the only way to change them is through a convincing demonstration that monetary and fiscal policies will not accommodate the expected inflation rate.

An example will serve to illustrate this point. Assume that 4 percent

11. An effect from such changes appears in equations estimated with quarterly data. The insignificance of lagged unemployment when added to the wage equations reported in table 5 argues against any important effects from a change in unemployment over a period as long as a year. I regard the correct specification as an open question in light of the differing results with quarterly and annual data.

12. William J. Fellner, Towards a Reconstruction of Macroeconomics: Problems of Theory and Policy (American Enterprise Institute, 1976).

13. Martin Neil Baily, in "Stabilization Policy and Private Economic Behavior," $B P E A, 1: 1978$, pp. 11-50, has recently explored the idea that the generalized expectation of prosperity has influenced the behavior of firms in a stabilizing way. Believing that the government will avoid the deep slumps of the past, firms themselves respond with hiring, stocking, and investment decisions that are more stabilizing than in the past. I interpret Fellner's views on inflationary expectations as analogous to this model of changing real behavior. 
real growth is the desired path for output and that 6 percent is the expected inflation rate. A 10 percent growth rate of aggregate demand would be accommodating. If aggregate-demand growth were held to 8 percent, the econometric evidence predicts that real growth the first year would slow by nearly 2 percent while inflation would slow only slightly. After two years, real output would be more than 3 percent below the 4 percent growth path, and prices would be about 1 percent below that path. Fellner reasons that, by making the decision to slow aggregate demand convincing, expectations would change and the division between real growth and inflation would improve. The coefficients of the model that yield pessimistic projections today would be changed by the clear determination of the authorities to adopt a nonaccommodating policy.

How plausible is this remedy for inflation? The 1973-75 recession apparently did not change the coefficients. It could be argued, however, that this period did not demonstrate nonaccommodation convincingly because policies promptly turned to aiding recovery once unemployment increased. Let me bring together the scattered evidence presented earlier for questioning Fellner's optimism.

First, the evidence is that the inertia process is expectational but to only a limited extent. That does not mean that people do not have expectations about inflation, but simply that current wage and price decisions, as opposed to decisions in other spheres such as lending or investing, are not governed by those expectations. Even in the area of long-term labor contracts, in which expectations could be important, the analysis presented above shows that wage developments are better explained as backward looking and that escalators are used to avoid predicting the future. For most questions regarding inflation it is not crucial to know whether the inertia process is forward looking or backward looking. It does matter here.

Second, even if the econometric coefficients from Phillips curves are interpreted as expectational rather than backward looking, how much will an announced policy of demand restraint affect those expectations? If a nonaccommodating aggregate-demand policy is totally convincing, it will lead people to expect that unemployment will rise. But why should this affect their expectations about inflation by more than the short-run Phillips curve predicts? If inflation responds weakly to actual unemployment, why should expected inflation respond so strongly to expected unemployment? 
This leaves room for a small gain in Fellner's scheme. If there are some wage contracts made with a view to the unemployment rate anticipated in the future, expecting more unemployment should modify such contracts by the amount predicted by the Phillips curve. If a restrictive nominal GNP path is to be pursued, there is thus some gain from announcing it ahead of time. My only question is whether there is reason to expect more than the improvement predicted by the Phillips curve as applied to the expected future course of unemployment. And if even that effect is confined to a small subset of contracts that are actually forward looking, the total benefits would be limited. On the price side, there are depletable resources whose price depends on expectations of prospective demand, but these are not important in the overall price level.

If wage and price setting were sufficiently concentrated in this economy, the possibilities for affecting inflation through Fellner's route would be greatly enhanced. A roomful of private decisionmakers who recognized that their inflationary behavior would directly affect their level of output and employment would be expected to respond favorably to a government policy of nonaccommodation. That is not what occurs in the U.S. economy.

Linking an incomes policy to an announced nonaccommodating policy on aggregate demand would help achieve Fellner's result. As discussed below, an effective incomes policy would produce a more favorable prospective split between real growth and inflation for any given path of nominal demand growth. Thus, expectations of inflation would change by more than the Phillips curve predicts. And to the extent that expectations do affect current wage decisions-which is still an open question-they would complement an incomes policy. Although it is an incomes policy that changes the immediate trade-off, the nonaccommodating demand policy is a necessary complement. Without it, the reduced inflation promised by the improved trade-off could be dissipated by a movement along the new trade-off curve.

\section{Slowing Inflation: Tax-Based Incomes Policies}

Although there are several variations of tax-based incomes policies (TIPs), their differences are primarily important in determining their acceptability, the ease of their implementation, and their effectiveness in altering individual wage and price decisions. These matters are discussed 
in other papers in this volume. At the macroeconomic level, the main impact of alternative TIPs affecting wages will be similar. And TIPs that act on prices primarily ensure that price restraint parallels wage restraint, which is what the macroeconomic model predicts without such policies.

It is simplest to integrate TIP effects into the macroeconomic model by assuming that the same path of real output is pursued with and without the program. Starting from the present state of the economy, a TIP that causes individual wages to rise more slowly than they otherwise would can be represented simply as a reduction in the constant term of the wage equation. Whether TIP will alter the slope of the short-run Phillips curve or whether it will reduce permanently the unemployment rate that represents full employment are separate issues that are briefly considered below. With a downward shift in the constant term of the wage equation, nominal aggregate demand must be reduced by an amount that is proportional to the shift in order to maintain the desired output path. This necessitates an appropriate combined adjustment in fiscal and monetary policies. This relatively simple procedure is all that is needed to integrate TIP and aggregate demand policies in the first year; a similar adjustment is required in subsequent years if the shift caused by TIP each year could be specified. But the macroeconomic analysis does raise some questions about the size of that shift in subsequent years and the difficulty of attaining it.

\section{LAGGED EFFECTS}

In most views of the inflation process, the slower average wage increases resulting from TIP in the first year will reduce wage pressures in the second year. If prices slow correspondingly, as would be expected, this favorable lagged effect would be predicted by any of the aggregate equations discussed earlier. Because the estimated lags are short, a major fraction of the first year's improvement in inflation will be perpetuated into the second year. In actual experience, however, some of the complications introduced by TIPs might lead to lagged effects that are different from these estimates.

Any TIP program may alter slightly the distribution of wages. The possibilities are numerous and the likely outcomes differ according to whether a penalty or reward TIP is employed. The main possibility for obtaining lagged effects that are noticeably smaller than the macromodel 
predicts probably arises in the case of a reward TIP that is employed for only one year. On the one hand, without a reward in the second year, workers whose wages had been restrained would tend to increase their wage demands to catch up with those that had not. On the other hand, firms that had not participated would be at a competitive cost disadvantage relative to firms that had, and that would put downward pressure on their wage offers. If these two influences cancel each other, the lagged effects from the economic equations should hold.

If the lagged wage effects in the macroeconomic model represent generalized expectations, the TIP program can be viewed in two ways. First, expectations that are based on actual experience should be favorably influenced by the initial slowdown in average wages and prices under TIP. This influence can be expected to grow if TIP effects are present over successive years. Second, expectations should be influenced by the existence of TIP as a specific and acceptable anti-inflation program. It should enhance the effects on inflationary expectations that Fellner looks for through policies of nonaccommodating aggregate demand. I have argued that these policies may be weak because their primary effect would be to change expectations of unemployment. Together with TIP, a greater part of any change in nominal demand expectations would be changes in expectations of the price level.

\section{CHANGING THE STRUCTURE}

TIPs are sometimes espoused as a means of shifting the Phillips curve in a favorable direction. This is one interpretation of shifting the constant term in the aggregate-wage equation. There is little basis, however, for judging whether such a favorable shift would be maintained in a period of substantially tighter labor markets. Because excess demand in the labor market now appears to develop gradually, TIP might make the Phillips curve more nearly L-shaped. In moderately tight markets, wages might be restrained, producing an improved trade-off; but in extremely tight labor markets, TIP might be relatively ineffective and the short-term trade-off might be the same as before.

TIPs do not have to reduce the unemployment rate that represents full employment in order to be useful. They would be a valuable tool if they were simply a shortcut to price stability and slowed the present wageprice spiral without a period of sustained high unemployment. If they 
were also an indirect remedy for structural problems in the labor market that produce inflation while involuntary unemployment still exists, that would be a bonus.

\section{Measures to Cut Costs and Prices}

What effect can we expect on the ongoing inflation rate from one-time increases or reductions in prices or costs? We can rely on cost changes to be reflected in prices. Beyond that, the empirical evidence is unfailingly ambiguous. The price shocks of the mid-1970s affected wages, but not proportionately. Consumer prices appear to have some persistent effect on wages, but it is modest once the effects of lagged wages themselves are allowed for. On the basis of the evidence, it appears that only a minor fraction of any shock to prices would filter through into average wage changes and thus have some multiplied effect. That still makes measures to cut prices and costs worth pursuing and their opposites worth avoiding. Even if only one-quarter of any price change influences wages, 1 percent removed from the CPI reduces wage inflation by about as much as 1 percentage point more unemployment for one year.

Measures to cut prices and costs can be effectively included as part of a larger anti-inflation strategy. In any such strategy, success will be selfperpetuating. Failure in the aggregate will almost surely cause the pieces to come apart. If the government can point to direct price-cutting measures of its own, it would stand a better chance of obtaining support from the private sector, either for voluntary restraint or for TIP. And if the government could accomplish that, it could change the inertia equations in a favorable way. 


\section{Comments and Discussion}

Martin Neil Baily: George Perry presents and discusses in an interesting and provocative way several hypotheses relevant to anti-inflationary policy. Perry describes convincingly the tremendous inertia in wage behavior during inflation and also brings out some new and informative aspects of the Phillips curve. I have a few doubts to raise, however, about his conclusions.

First, Perry shows the relatively greater inflexibility of wages in the high-wage and union sectors. The low-wage and nonunion sectors appear to be more responsive to short-run economic conditions. This result is plausible and can be rationalized, for example, on the grounds that wage contracts are more important in the high-wage and union sectors. The disaggregated wage equations that Perry estimates, however, contain no variables that will hold the wage distribution together. In BPEA, 2:1977, James Tobin and I developed some results suggesting the importance of the relative sectoral wage level as a determinant of the rate of change of a sector's wage. Perry does not have to accept our formulation, but one would expect some variable to be included that prevents relative wages from diverging indefinitely. In the past few years union wages have increased relative to nonunion wages. This fact is interesting in itself and relevant for wage policy. But if union wages continue to grow faster than nonunion wages, there will surely be increasing stress in the wage structure that will eventually affect the rates of change of wages in both sectors.

Second, Perry argues that the true wage equation is characterized by a "catch-up" augmented Phillips curve, rather than by an expectationsaugmented Phillips curve. The arguments for this view seemed to me unconvincing. To demonstrate this would require an analysis of how expectations are formed and how the catch-up is computed, realizing that these 
two are different in principle and that they have in fact behaved differently enough over some historical period that the data can test the two alternatives. To be more specific, given all the shocks that have hit the economy recently and the tremendous inertia evident in wage behavior, it may have been true that the best estimate of one year's wage increase was the previous year's wage increase. If even half-true, this would make the two hypotheses difficult to distinguish.

Third, I was puzzled by two aspects of Perry's procedure and so I reran his aggregate equation. I was surprised that his wage-wage equation did not allow for serial correlation of the errors, but I discovered that this was because the correction made only a minor difference. Perry himself notes that the price feedbacks do seem to decline in importance with a serial correlation correction. However, I came to a different conclusion than Perry did regarding the stability of the equation. His predictions are made using actual values of the feedback variables rather than the predicted values from previous periods. This is a great help in keeping the equation on track through the 1970s. My version of Perry's equation 5.4 (the unemployment rate for adult males used in place of the weighted aggregate rate) underpredicted the rate of wage inflation in every year from 1971 through 1977 and gave a cumulative underprediction of over 16 percent by 1977 .

In faimess to Perry, I should point out that he does say that the wagewage spiral alone cannot explain the behavior of the 1970s. This is a crucial point for both theory and policy, however, and requires more emphasis. It is difficult to avoid the conclusion that the rapid price inflation and slow growth of real wages in the 1970s caused an upward pressure on wage settlements, particularly in the union and high-wage sectors, as Perry's earlier results suggested. The only other alternative is to argue that Perry has sharply underestimated the true nonaccelerating-inflation rate of unemployment (NAIRU) or natural rate. Wage acceleration has occurred, in this alternative view, because the actual unemployment rate for 1971-77, which averaged 6.5 percent, was below the NAIRU.

As a final check on the stability of the Phillips curve, I ran an F-test to see if the coefficients of the wage-wage or wage-price equations had shifted significantly. The null hypothesis was that the coefficients had remained constant across the 1956-69 and 1970-77 periods. These dates were selected because the lack of responsiveness of wages to the 1970-71 downturn was seen by many observers as an important break in wage 
behavior. The null hypothesis was rejected at the 5 percent level for my calculations of Perry's wage-wage and wage-price equations.

In short, therefore, $I$ am less confident than Perry that we really do have a stable structural relation in current Phillips curve specifications. However, there are two lessons that Perry wants us to learn from the 1960s and 1970s. If the economy is wound up too much, wages and prices begin to accelerate. If unemployment is raised to slow things down again, it is a painful process. I have no quarrel with either of these lessons.

The regressions on inflation against the deficit and on inflation against money growth are fun. I hope the myth about the deficit is diminished by these findings. The improved performance of money growth as an explanation of the 1972-77 inflation does not give greater support to the monetarist than to the structuralist view of inflation. The Federal Reserve Board is not immune from political forces, nor should it be. It cannot tolerate prolonged, excessive unemployment. If structural factors push out the inflation/unemployment trade-off-resulting in inflationary price pressure even at high unemployment-the Federal Reserve Board is forced to accommodate at least some of this pressure. Consequently, high inflation and high money growth will tend to go together, even with a structuralist perspective.

Perry presents a brief discussion of the misperception theories. I think these theories can accommodate layoffs better than Perry indicates, but I share his general skepticism that expectational errors can plausibly explain the persistence of unemployment movements. And this also leads me to agree with his mistrust of the use of policy announcements to reduce inflationary pressure directly.

In conclusion, I commend Perry for his interesting and stimulating paper. If it did not convince me on all points, this merely reflects the difficulty of the issues being tackled.

William Poole: The basic message of George Perry's paper is that the Phillips curve is alive and well and that the evidence continues to support the proposition that higher unemployment buys a distressingly small rate of deceleration in inflation. I do not have any major quarrels with Perry on the matters analyzed in his paper.

For the purposes at hand it is not necessary to say much about the theory behind the Phillips curve. Perry is clearly writing within what may 
be called the original Phillips curve tradition, as distinguished from the more recent view of the curve developed by Milton Friedman, Edmund Phelps, and Robert Lucas. Under the traditional view, wage and price behavior-supported by contractual, collective bargaining, and other institutional considerations-reflects a substantial degree of inertia, whereas according to the view held by Friedman, Phelps, and Lucas, inertia is not inherent in behavior but reflects correctly perceived inertia in inflation caused by the monetary policies of the government. The importance of distinguishing between these two views is that according to the traditional view, demand management can reduce inflation only slowly and painfully, while under the alternative view, expectations could in principle be altered relatively quickly and, therefore, at little unemployment cost.

Perry attempts to provide evidence on this issue by examining what he calls forward-looking and backward-looking Phillips curve specifications. I find his evidence supporting the backward-looking specifications unconvincing. Consider, for example, the implications of the forward-looking theory for the apparently backward-looking wage-wage specification. Suppose wages are set on the basis of a price forecast for the next several years. Clearly, in trying to explain the wage behavior of the current year, last year's wages could be a more accurate measure of current expectations of future inflation than any proxy constructed from past or future price changes. I believe that it is simply not possible to obtain convincing evidence on this issue from the approach Perry follows.

From other evidence there can be no question that forward-looking behavior is important. The increasing use of cost-of-living clauses reflects a structural modification to contracts in anticipation of continuing inflation. In nonunion situations many companies have apparently replaced annual salary reviews with semiannual reviews so that wages can be linked more closely to changes in price level. And evidence from episodes of hyperinflation in other countries makes it clear that institutional practices seemingly anchored in bedrock are adjusted amazingly rapidly when inflation reaches triple-digit and higher rates.

If Perry underestimates the importance of forward-looking behavior, as I think he does, the near-term policy significance of this issue is nevertheless limited. Even the most ardent believer in the importance of expectations has a difficult time finding policy proposals that promise to gen- 
erate a quick and lasting change in inflationary expectations. Suppose, for example, that the Federal Reserve announced that money growth would be reduced to a 4 percent annual rate immediately and then held at that rate indefinitely. It would be unlikely that this announcement would change inflationary expectations. The Federal Reserve has not always achieved its announced money growth targets; moreover, there is a possibility that the President, the Congress, or both would force a change in Federal Reserve policy if a recession occurred. From this viewpoint, the problem is not an economic policy problem at all, but rather one of constructing a political consensus for a noninflationary monetary policy.

It is unlikely that long-run inflationary expectations can be reduced without an actual decline in inflation and clear evidence of a commitment to less inflationary policies. For the evidence to be clear, it may well be necessary for the government consciously and deliberately to avoid following expansionary policies in the next recession.

If Perry's estimates are taken at face value, a monetary policy that kept the unemployment rate 1 percentage point above the natural rate would be consistent with a decline in the inflation rate by 0.3 percentage point each year. That policy would then call for a deceleration of money growth sufficient to slow nominal GNP growth by 0.3 percentage point a year. With this policy it would take at least twenty years of unemployment at 1 percentage point above the natural rate to reduce the inflation rate to zero. (Indeed, with Perry's two-year lag structure, it would take nearly thirty years.) It is difficult for me to believe that prediction of the results of such a monetary policy; surely in time the policy would change expectations and lead to adaptations consistent with full employment on the average. Nevertheless, Perry's estimates may well be reasonable for the time required for changed policies to become credible and to affect expectations. This period could easily be three to five years.

A number of policy proposals, including tax-based incomes policies, should be viewed in the light of their prospects for reducing the unemployment costs of the more basic anti-inflationary policy of slowing money growth. Perry mentions, but insufficiently emphasizes, the importance of reducing nominal income growth. Without monetary deceleration, other policies to reduce inflation are absolutely guaranteed to fail; with monetary deceleration, these other policies may reduce the employment costs of slowing inflation. 
Perry does not discuss this possibility in detail, but I think that the importance of nonmonetary policies for the inflation issue is primarily political and expectational. The economics of these policies should be judged on efficiency and public finance considerations.

\section{General Discussion}

William Fellner amplified his views on anti-inflationary policy. He agreed with Perry that reasonably optimistic views about the output and employment consequences of his demand policy implied changes in specific regression coefficients in response to a consistent and credible policy line. He suggested that the coefficient that would change could be identified, for example, in a model of the type developed in Phillip Cagan's current work. For a slack of given size, this is the coefficient by which it is necessary to multiply the difference between the expected long-run inflation rate and the currently observed rate to obtain the current downward revision of the expected long-run rate. This revision causes current price deceleration, which either is added to the deceleration resulting from any increase in the slack or is deducted from the price acceleration resulting from any decrease. Fellner suggested that, under a credible policy of gradually reducing the rate of increase of money GNP until inflation is eliminated, the numerical value of the coefficient determining the adjustment of price-trend expectations would increase significantly. This, he argued, is because the erratic policies of the past must have made the public hesitant to lower its long-run inflation expectations during the brief periods of nondiminishing slack. Fellner also said that the alternative to the course he is advocating would be an uncomfortably controlled system, rather than the kind of economy envisaged by the advocates of incomes policy.

Michael Wachter agreed with Fellner on the importance of the changing responsiveness of inflation to government policy actions and pronouncements. Wachter said that the government had actually reduced the effectiveness of its anti-inflation policy and increased confusion during the most recent recession by frequently stating that policy was much less contractionary than it actually was.

James Tobin noted that if a TIP scheme were successful, the nominal 
money stock should grow less rapidly than if such a scheme were not in effect. He cautioned against accompanying a TIP scheme with aggregate demand policies that are contractionary in real terms.

Robert Gordon said that it was clear from the evidence of the 1960s and early 1970s that wages do not adjust fully to accelerations in the consumer price index; but he considered current knowledge about the effects of other wage determinants uncertain. In particular, he stated that it would be difficult to distinguish between the influence of product prices and the influence of other wages because of the high collinearity in these variables. Franco Modigliani reported that the coefficient on wages had been inappropriately negative in wage regressions with both past wages and past prices as independent variables. Perry responded that this result came from using hourly compensation as a wage variable; such compensation is currently poorly measured and is influenced by many nonmarket events such as payroll tax changes. Edward Gramlich argued that wages tend to be considerably more inflexible than prices in the U.S. economy. Thus, the use of longer lags might lend support to a price-wage hypothesis. Wachter voiced the opinion that the lagged money supply would perform as well as lagged prices or wages in explaining wage inflation. But Modigliani agreed with Perry that money supply or fiscal policy have no effect above that already captured by the excess demand variable.

Other participants at the conference discussed whether expected or past prices were more important in determining wages. Frederic Mishkin suggested that the presence in wage equations of only short lags on price inflation did not provide evidence supporting backward- rather than forward-looking wage behavior. If the inflation rate followed a random walk, for example, the most recent inflation rate would be the best predictor of future inflation rates. Therefore, even if wage behavior was forward looking, the most recent inflation rate would contain all the relevant information about expected inflation. Mishkin emphasized, however, that the relationship between past and expected price inflation need not be a stable one and might depend on the exact nature of the inflationary process. Thomas Juster said that short-run inflationary expectations were more volatile than long-run expectations and that long-run rather than short-run expectations were relevant for wage determination. This suggested the need to use longer lags.

Gardner Ackley and James Duesenberry questioned the usefulness of searching for a single determinant of wages. Duesenberry noted that there 
were good microeconomic reasons for product prices, consumer prices, and other wages to enter the process in both a retrospective and a prospective form. Greater disaggregation would be required to distinguish their relative importance. This uncertainty suggested that policies should not be adopted that depend too heavily on any single explanation. Ackley reasoned that each of these variables might be important to different sectors at various times. As inflation increased, institutional innovations, such as cost-of-living allowances, might well lead to changes in the relative importance of different variables.

The discussion turned to the behavior of relative wages. John Shoven suggested that the larger recent increases in wages in the high-wage industries might be explained either by the greater use of cost-of-living allowances in the high-wage unionized sector, or by the fact that as skilled wages moved into higher marginal tax brackets a larger before-tax dispersion was required to maintain the same after-tax differentials. Duesenberry mentioned Perry's evidence that wages in the high-wage sector were more sensitive to inflation and less sensitive to unemployment than those in the low-wage sectors. If the Phillips curve in the high-wage sector were flatter than that in the low-wage sector, it was likely they would intersect; if they did not, it would not lead to the cumulative divergence in wages that concerned Martin Baily in his discussion.

Modigliani and Robert Hall said that Perry had treated the rational expectations school too casually. Hall stated that Perry should have discussed the new view of this school-that recent changes in the inflation rate have been caused by changes in the natural rate because of supply shifts. Despite this omission, he agreed with Perry's Keynesian conclusion that changes in aggregate demand influence output far more than prices. Perry replied that he had not tried to present a comprehensive discussion of the rational expectations view but simply discussed where it differed from the mainline model. The principal difference is that the mainline model recognizes the possibility of extended periods of cyclical unemployment, while the rational expectations model treats such occurrences as changes in the natural rate. 